\title{
EFFECT OF FEEDING DIFFERENT CONCENTRATE ROUGHAGE RATIO ON GROWTH, REPRODUCTIVE PERFORMANCE AND BEHAVIOR OF SHEEP
}

\author{
Anaam E. Omar ${ }^{1 *}$, Heba S. Gharib², Enas N. Said ${ }^{2}$
}

${ }^{1}$ Department of Nutrition and Clinical Nutrition, Faculty of Veterinary Medicine, Zagazig University, 44511, Egypt, ${ }^{2}$ Department of Veterinary Public Health, Faculty of Veterinary Medicine, Zagazig University, Egypt

*Corresponding author, E-mail: dr.anaamomar85@gmail.com, madamreda72@yahoo.com

\begin{abstract}
The goal of this study was to examine the influence of feeding different concentrate roughage ratios on growth, reproductive parameters and behavior of sheep. The study design involved the use of a 30 sexually mature ewes assigned to three groups consisting of three ratios of concentrate (C) to roughage (R), Group1. $80 \% \mathrm{C}: 20 \% \mathrm{R}$, Group2. 70\%C: 30\%R and Group3. 60\%C: 40\%R. The variables of the studies were live weight changes and Body condition score (BCS) of ewes during pregnancy and postpartum till weaning and behavior of ewes in addition to the birth weight and average daily gain of neonatal lambs and subsequent changes till weaning. The conception rate of ewes and their overall reproductive performance are under investigation. The results reveled that, different ratios of concentrate and roughage feeding had no significant effect on body weight, BCS and average dry matter intake of ewes during pregnancy and postpartum till weaning. Lambs birth weight and subsequent weights till weaning and average daily gain were significantly $(P \leq 0.05)$ increased by feeding on ration contain $80 \% \mathrm{C}: 20 \% \mathrm{R}$, followed by those feeding on $70 \% \mathrm{C}: 30 \% \mathrm{R}$ and lowest in those feeding on $60 \%$ C: $40 \%$ R. Rumination was significantly increased in Group3 lambs than other groups. Higher concentrate ratios had positive effect on reproductive performance of ewes and body weight, daily body weight gain and neonatal behavior of lambs till weaning.
\end{abstract}

Key words: concentrate; roughage; ewe; lamb; growth performance; behavior

\section{Introduction}

There are about 5.6 and 4.13 million heads of sheep and goats in Egypt (1). Sheep and goat production constitute a major part of Bedouins income but in extensive system of production, quality and quantity of pastures affected by weather and environmental changes which would affect feeds availability and quality for sheep (2). These changes had an effect on the nutrition and performance of lambs and their dams. Above pasture conditions would have an impact on birth weight, on quantity of milk production and on weaning weight of lambs. Behavioral understanding is essential for the performance enhancement of sheep on grazing, mainly due to intense climate changes which influence animal physiology. However, it is important to enhance the utilization of pastures 
and applying strategies for nutritional management achieving the system highly productive (3).A study in India by (4) also reported significant effect of raising lambs on ADG under intensive system where lambs feed on complete rations compared with extensive system.

Feed quality and quantity are the main factors affecting ruminant productivity under tropical conditions, providing large quantities of concentrated feeds in the diet increase energy density of the diet that may improve feed efficiency and animal performance (5) however, feeding on high concentrate diet for long time may be result in decreased ruminal $\mathrm{pH}$ due to accumulation of volatile fatty acids and lactic acid and cause chronic digestive disorder (6). Therefore, feeding on proper concentrate level is one of the most important factors to ensure the growth and reproduction of ewes and their lambs. Nutrition play important role on reproduction performance of ruminant animals (7) also affect the onset of postpartum ovarian cyclicity of ruminant animals (8) but there is lack of information regarding the effects of diet on the lambing rate and overall reproductive efficiency of the fattailed sheep. In a study, (9) showed that high concentrated feed caused higher ovulation rate and less ova viability. The survival of a neonatal is mainly depending on vigor (the ability to stand up and suck milk during a few hours after birth), maternal behavior and colostrum production. These factors are influenced by the ewe's level of nutrition during late pregnancy $(10,11)$.

The objectives of our study are to define appropriate concentrate roughage ratio that ensure high growth and reproduction performance and behavior of ewes and their lambs.

\section{Materials and methods}

This study was conducted at private farm belonging to Sharkia governorate, Egypt.

Animals, housing, diets and experimental design
A total of thirty Baladi ewes were purchased locally and selected on the basis that they had lambed at least once before. Their body weights ranged between 40 to $50 \mathrm{Kg}$ and their ages varied between 2.5 to 3 years. They were identified by ear tags, vaccinated against pasteurellosis, sheep pox, colostridial, pestedespetits ruminant (PPR) and enterotoxaemia potential infections. The ewes were exposed to the feedlot housing management and feeding as confined animals (zero grazing). Ewes were randomly divided considering age and body weight in to 3 experimental groups (10 ewes/ group) with 10 replicates of 1 ewe in each (Group1. 80\%C: 20\%R, Group2. 70\%C: 30\%R and Group3. $60 \% \mathrm{C}: 40 \% \mathrm{R}$ ) in different stages of the reproduction of ewes. Daily observation was carried out on animals for any health disorders. No mortalities were occurred among different groups during the whole experimental period. The sheep sheds were respectively cleaned thoroughly and disinfected to eliminate any possible infection that transferred from previous sheep flocks. The water and feeding troughs were also cleaned. Individual housing for each animal in individual pens with feed and water troughs. All animals were reared under the same management condition. Ewes lambed indoor and new born lambs live together with their dams in individual pens. Lamb weight was calculated at birth and fortnightly till weaning.

The experimental diets were formulated according to specific requirements of ewes (12) as shown in Table 1. Experimental feeds were analyzed for (DM, Moisture, CP, CF, EE and Ash) according to (13). The animals were fed individually twice daily, equally dividing concentrate and roughage components, once in the morning between 6.00 and 7.00 AM, and again between 5.00 and 6.00 PM. The left-over feed was collected on a daily basis in the morning. Actual intake of the concentrate mixture and roughages were recorded.

\section{Growth performance of ewes and lambs}

The ewes were individually weighed at beginning of experiment to obtain the average initial body weight then the body weight was 
recorded monthly during pregnancy period and biweekly after lambing till weaning of lambs to calculate the average body weight of the animals in each group. Feed intake of each ewe was recorded as the difference between weight of the feed offered and residues left. The birth weight of new born lambs was taken within one hour after birth. The subsequent weight of lambs was recorded fortnightly in the morning and before feeding up to weaning. The lambs weight gain was measured as the difference between final body weight at the intended period and primary body weight at same period.

\section{Body Condition Scoring Procedures}

The BCS evaluates the body fat reserve of the sheep and was determined by examining the tail head and the loin areas according to (14). The BCS of sheep was measured by feeling the backbone and the transverse processes of vertebrae in the loin region by the finger.

\section{Reproductive performance}

The ewes were treated with progestogenimpregnated $(30 \mathrm{mg})$ intravaginal sponges for 14 days. After $14 \mathrm{~d}$, the sponges were withdrawn and 400 I.U. of Pregnant Mare Serum Gonadotropin (PMSG) was injected intramuscularly. The ewes were then introduced to rams for natural mating. The number of conceived ewes and number of lambs born a live and number of abortion and still birth were recorded. Litter size was calculated as total number of lambs born / total number of ewes. The live weight of lambs was measured within one hour after lambing.

\section{Behavior measurement}

Focal sampling technique was used to record the time spent by ewes with each behavior. The behavioral activities were recorded through 10 hours (from 7.00 am till $17.00 \mathrm{pm}$ ) per week at 10 minutes interval. Behavioral traits recorded are eating, drinking, rumination, standing, walking, lying, urination and defecation. Eating: the mean time (min) spent in eating ration per 10h observation, Drinking: The mean time (min) spent in drinking water per 10 hours observation, Rumination: the mean time (min) spent in rumination /10h observation. Standing:
The time (min.) spent in standing without doing any activities during $10 \mathrm{hr}$, observation, Lying: time (min) spent in lying on the ground during 10hr observation, Defecation: when ewe makes voiding of food and water that are not retained in the body for metabolic processes as a solid material from the anus (faeces), Urination: when ewe makes voiding of water that are not retained in the body for metabolic processes as a liquid. While the data for neonatal lambs were collected for the first 2 hours following lambing. The observer recorded the duration in minutes that the neonate spent to be able to stand up without help, to reach udder (approach udder and nudge the inguinal region), time to suck (holding the teat with its mouth and appears to be sucking for more than 5 seconds) and the suckling attempts as described by $(15,16)$. Behavior was evaluated by an observer stood up 2 meter from the pen using an observation sheet, a stop watch and a photograph during the observation period.

\section{Statistical analysis}

The collected data were subjected to analysis of variance using one-way ANOVA using SPSS 24.0 for Windows (SPSS Inc., Chicago, IL, USA) and the differences between experimental groups were calculated by Duncan's multiple-range test at $(P \leq 0.05)(17)$.

\section{Results and discussion}

In this study three ratio of concentrate and roughage diets were considered and hypothesized as main contributing factors affecting the productive and reproductive performances of ewes under the feedlot (zero grazing) management system.

The effect of $\mathrm{C}$ : $\mathrm{R}$ ratios assigned to $80 \% \mathrm{C}$ : 20\%R, 70\% C: $30 \% \mathrm{R}$ and $60 \% \mathrm{C}: 40 \% \mathrm{R}$ on the live weight and BCS of ewes during pregnancy and after parturition till weaning are presented in Table 2. No significant ( $P \geq 0.05)$ influence of $\mathrm{C}: \mathrm{R}$ ratios on live weight and $\mathrm{BCS}$ of ewes are observed. Our data disagree with results of previous studies where the final live weight and total live weight gain of does increased with higher level of concentrate supplementation $(18,19,20)$, moreover (21) reported that ewes 
under sub-feeding level $(0.500,0.750$ and 1.00 $\mathrm{kg}$ concentrate /ewe) during first 15 weeks of pregnancy, last 6 weeks of pregnancy and 60 days from parturition till weaning, respectively had lower final weight and BCS than those fed on normal (0.750, 1.00 and $1.25 \mathrm{~kg} / \mathrm{ewe})$ and high concentrate level $(1.00,1.25$ and $1.5 \mathrm{~kg}$ lewe). The lack of our effect on growth performance of ewes might be related to the management practice, genetic factor, composition of basal diets (diets are isonitrogenous) and constant feed intake (22).

Average daily DM intake of ewes for the entire duration of feeding periods covering the pregnancy and lactation periods was shown in Table 3. The results showed that different ratio of concentrate and roughage had no effect on average dry matter intake/ewe through advanced weeks of experiment from 1-28 weeks. The lack of effect on DM intake may be due to the diets were isonitrogenous (22). Our results were consistent with previous researches in goats were DM intake was not affected with increasing concentrate percentage in diet from $30 \%$ to $70 \%$ (23) and (24) in Holstein cow were increasing forage concentrate ratios (47:53, 54:46, 61:39 and 68:32) had no effect on dry matter intake. In contrast feeding high level of concentrate increase dry matter intake of goat (18) moreover, (25) found that increasing concentrate percentage in diet from $30 \%$ to $60 \%$ increasing dry matter intake of dairy goats. Similarly, cow fed on 30\% forage: $70 \%$ concentrate diet had significantly higher dry matter intake than those fed on $50 \%$ forage: $50 \%$ concentrate diet (26).

\section{New born lamb performance}

It is important that farmers feed their animals cheap, effective feed ingredients to remain gainful in the face of increasing feed prices. How quickly and efficiently the lambs grow is most important agents affecting economic capability in livestock production. High growing rate of lambs reduce the time needed to reach market weight, which in turn reduces the employments and the feed costs associated with raising of lambs. Composition and quantity of milk are essential for newborn lambs as the milk supplies the main nutrients needed (27), so growth rate of suckling lambs increase if the quantity or nutritive composition of the milk increase.There are also non-genetic factors can affect the lamb growth rate, one of them is system of production, the results showed that the feed lot rations were related with improved lamb growth rates, bigger carcass fatness and better dressing percentage (28).

The birth weight and biweekly changes of live weight of new born lambs till weaning are shown in Table 4. The mean lambs birth weight was significantly $(P \leq 0.05)$ increased by greater concentrate level feeding. The average BW and ADG at week 2 were significantly $(P$ $\leq 0.05$ ) increased in group1 in comparison with group $2 \& 3$. The average body weight and ADG at week 4 were significant $(P \leq 0.05)$ the highest in lambs fed on $80 \% \mathrm{C}: 20 \% \mathrm{R}$ followed by lambs fed on $70 \% \mathrm{C}: 30 \% \mathrm{R}$ and lowest in lambs fed on $60 \% \mathrm{C}: 40 \% \mathrm{R}$. The lambs fed on 80\%C: $20 \% \mathrm{R}$ had $(P \leq 0.05)$ significant higher average BW and ADG at week 6 and 8 followed by lambs fed on $70 \% \mathrm{C}$ : $30 \% \mathrm{R}$ while lambs fed on $60 \% \mathrm{C}$ : $40 \% \mathrm{R}$ had the lowest. Overall ADG was significantly $(P \leq 0.05)$ increased by feeding higher levels of concentrate and it is the highest in group 1 and lowest in group 3. Our results of increasing ADG of lambs with increasing concentrate level in diets are consistent with results of $(29,30,31)$. Also, $(32,33)$ indicated that the ADG and FCR of lambs were better in high concentrate diets than low $\mathrm{C}$ diets under intensive system of production. Similar types of observations were also recorded by $(34)$ in lambs, $(18,35)$ in kids. However, our data disagree with result of (21) who observed no significant effect on lamb birth weight by feeding different levels of concentrate (0.750, 1.00 and $1.25 \mathrm{~kg} / \mathrm{ewe})$. Growth rate of kids feeding different levels of concentrate did not significant different (20). There was no effect of increasing levels of concentrate on feed intake, final live weight, ADG, FCR in lambs (36).

Effect of concentrate: roughage ratio on behavior of pregnant and lactating ewes 
Data in the Table 5 revealed that the concentrate percent in ration had no significant impact on most of maintenance behavior of pregnant and lactating ewes. Regarding ingestive behavior, it is observed that ewe fed on Group 3(60\%C: 40\%R) spent longer eating time than other rations (Group 1and Group 2). These results may be explained to the fact that rapid consumption of concentrates by animals. Our results are in accordance with (22) who found that the eating time was decreased linearly with increasing the concentrate level. The time spent ruminating was significantly higher in pregnant and lactating ewes of group fed on $60 \% \mathrm{C}: \quad 40 \% \mathrm{R} \quad(12.26 \pm 0.38$ and $11.26 \pm 0.4 \mathrm{~min} / \mathrm{h}$ respectively) than other groups. This may explained to more time needed to ruminate the forage. In a reverse trend, (22) noted that the level of concentrates had no effect on time spent in rumination. Diets rich with concentrate prefered time spent in ruminating during the day while time spent in resting through the night (37).

\section{Effect of concentrate: roughage percent on} neonate lamb behavior

The impact of different ratio of concentrate and roughage during pregnancy on some neonatal lamb behavior are listed in Table 6 generally Group 1, Group 2 and Group 3 lambs showed significant behavioural differences. Lambs' response time to stand was shorter in Group 1 lambs, search for the udder and also response times to first suckling were significantly shorter at Group 1 lambs. Supplementation of high concentrate in peripartum period has an impact on lamb vigour. Lambs' response time to stand up without help, search for the udder and also response time to first suckling were significantly shorter in Group 1 neonates in comparison with other groups. These results were comparable with the results described in other sheep breeds (38). Beginning of suckling could achieve after a longer time because Group 2 and Group 3 neonates tend to tumble more times comparing to Group 1 neonates. Postpartum Group 1 ewes moved and cleaned their neonates more frequently, and depending on their maternal experience which can stimulate lamb activity (39). Feeding supplies at birth had an impact on lamb strength. Generally, latency to standing and suckling was slower in low-birth weight lambs than heavier lambs. Lamb vigor is affected by amount of adipose tissue and locomotor ability. Brown adipose tissue provides the neonate lamb with energy needed for thermoregulation and nutrition from birth till colostrum intake (40). Development of CNS of lamb, and subsequently locomotor activity, may be impacted by the nutrition of dam through pregnancy (41).

\section{Reproductive performance of Ewes}

In sheep production operations, the producers are interested in the number of ewes becoming pregnant, lamb born alive and lambs survive till weaning and then finishing for the markets. These important variables were summarized showing dietary influences in Table 7 . About $80 \%, 50 \%$ and $40 \%$ of ewes fed groups 1, 2 and 3 respectively conceived producing a total of 8,5 and 4 lambs from 10 ewes joined. No abortion or still birth has been reported. All births were for single lamb. The conception rate for ewes was higher in ewes fed on $80 \% \mathrm{C}$ : $20 \% \mathrm{R}$ followed by ewes fed on $70 \% \mathrm{C}: 30 \% \mathrm{R}$ then ewes fed on $60 \% \mathrm{C}: 40 \% \mathrm{R}$. No twin birth was observed. The average litter size was higher in group 1 compared to groups 2 and 3. Group 1 was found to have more lambs born/ewe than other two groups. Reproductive performance of the sheep was known to be one of the major factors determining the efficiency of their production (42). Seasons of production, nutrition, breed, age, management and environment are some factors that affect reproductive activities on sheep $(43,44)$. Our results are consistent with results of (19) where the concentrate supplementation had positive effect on litter size and birth weight of kids moreover, concentration feeding had positive effect of reproductive traits of goat (20). (21) reported no effect of feeding different levels of concentrate on lambing, fecundity or prolificacy rates. In earlier work, (45) observed that the level of feeding or energy in the diet is 
a major influencing factor on the birth weight of the lambs. The ewes receiving high energy diet during the last trimester of pregnancy gained more live weight than those receiving low energy diets. (46) found that the ovulation rate of induced estrus increased with improved nutritional regime of ewes, therefore the conception rate and litter size were significantly and positively influenced by the interaction of nutrition and induced estrus. . However, (47) reported no effect of nutrition on estrus and ovulation rate of ewes.

Table 1: Proximate and chemical composition of Experimental diets

\begin{tabular}{|c|c|c|c|}
\hline Ingredients & $\begin{array}{c}\text { Group 1 } \\
(80 \% \text { C: } 20 \% \text { R) } \\
\end{array}$ & $\begin{array}{c}\text { Group 2 } \\
(\mathbf{7 0 \%} \text { C: } \mathbf{3 0 \%} \mathbf{R}) \\
\end{array}$ & $\begin{array}{c}\text { Group3 } \\
(60 \% \mathrm{C}: 40 \% \mathrm{R}) \\
\end{array}$ \\
\hline \multicolumn{4}{|l|}{ A. Concentrates } \\
\hline Wheat Bran, kg & 32.4 & 23 & 9.00 \\
\hline Corn, $\mathrm{kg}$ & 34.5 & 33 & 35.5 \\
\hline Soyabean Meal (48\%),kg & 11 & 12 & 13.5 \\
\hline *Vit. \& Min. Premix, kg & 0.3 & 0.3 & 0.3 \\
\hline Limestone, $\mathrm{kg}$ & 100 & 0.6 & 0.2 \\
\hline Calcium dibasic & 0.3 & 0.6 & 1.00 \\
\hline \multicolumn{4}{|l|}{ Phosphate, kg } \\
\hline Salt, kg & 0.5 & 0.5 & 0.5 \\
\hline Total A, kg & 80.00 & 70.00 & 60.00 \\
\hline \multicolumn{4}{|l|}{ B. Roughages } \\
\hline Alfalfa Hay, kg & 10.00 & 15.00 & 20.00 \\
\hline Wheat Straw, kg & 10.00 & 15.00 & 20.00 \\
\hline Total B, kg & 20.00 & 30.00 & 40.00 \\
\hline Total A + B, kg & 100 & 100 & 100 \\
\hline \multicolumn{4}{|l|}{ Chemical composition } \\
\hline $\mathrm{DE}, \mathrm{Kcal} / \mathrm{Kg}$ & 2545 & 2529.2 & 2554.1 \\
\hline $\mathrm{CP}, \%$ & 14.07 & 14.09 & 14.05 \\
\hline EE, $\%$ & 2.23 & 2.03 & 2.00 \\
\hline $\mathrm{CF}, \%$ & 9.31 & 9.24 & 10.44 \\
\hline $\mathrm{Ca}, \%$ & 0.66 & 0.67 & 0.69 \\
\hline Available phosphorus $\%$ & 0.53 & 0.52 & 0.51 \\
\hline
\end{tabular}


Table 2: Effect of feeding different concentrate roughage ratio on live weight $(\mathrm{kg})$ and body condition score (BCS) of ewes during pregnancy and after parturition till weaning.

\begin{tabular}{|c|c|c|c|c|c|}
\hline Period & Variable & $\begin{array}{c}\text { Group 1 } \\
\text { (80\%C:20\%R) }\end{array}$ & $\begin{array}{c}\text { Group } 2 \\
(70 \% \mathrm{C}: 30 \% \mathrm{R}) \\
\end{array}$ & $\begin{array}{c}\text { Group3 } \\
(60 \% \mathrm{C}: 40 \% \mathrm{R}) \\
\end{array}$ & $P$-value \\
\hline \multicolumn{6}{|l|}{ During pregnancy } \\
\hline \multirow[t]{2}{*}{ First month } & Weight & $46.30 \pm 3.16$ & $44.71 \pm 4.16$ & $44.29 \pm 4.28$ & 0.498 \\
\hline & $\mathrm{BCS}$ & $3.00 \pm 0.00^{\mathrm{a}}$ & $3.00 \pm 0.00^{\mathrm{a}}$ & $2.78 \pm 0.26^{\mathrm{b}}$ & 0.006 \\
\hline \multirow[t]{2}{*}{ Second month } & Weight & $48.43 \pm 2.10$ & $47.27 \pm 3.96$ & $46.46 \pm 5.04$ & 0.566 \\
\hline & $\mathrm{BCS}$ & $3.00 \pm 0.00$ & $3.00 \pm 0.00$ & $2.89 \pm 0.22$ & 0.123 \\
\hline \multirow[t]{2}{*}{ Third month } & Weight & $49.10 \pm 3.82$ & $48.96 \pm 3.96$ & $48.68 \pm 4.76$ & 0.976 \\
\hline & $\mathrm{BCS}$ & $3.10 \pm 0.21$ & $3.06 \pm 0.18$ & $3.06 \pm 0.17$ & 0.857 \\
\hline \multirow[t]{2}{*}{ Fourth month } & Weight & $51.50 \pm 3.11$ & $51.21 \pm 6.28$ & $50.57 \pm 3.98$ & 0.903 \\
\hline & $\mathrm{BCS}$ & $3.40 \pm 0.21$ & $3.25 \pm 0.27$ & $3.17 \pm 0.25$ & 0.123 \\
\hline \multirow[t]{2}{*}{ Fifth month } & Weight & $57.01 \pm 5.78$ & $56.13 \pm 2.25$ & $55.68 \pm 3.78$ & 0.801 \\
\hline & $\mathrm{BCS}$ & $3.65 \pm 0.24$ & $3.56 \pm 0.32$ & $3.44 \pm 0.18$ & 0.227 \\
\hline \multicolumn{6}{|l|}{ Postpartum to Weaning } \\
\hline \multirow[t]{2}{*}{ At Birth } & Weight & $51.86 \pm 2.76$ & $55.44 \pm 7.36$ & $49.50 \pm 2.38$ & 0.226 \\
\hline & $\mathrm{BCS}$ & $3.50 \pm 0.35$ & $3.58 \pm 0.38$ & $3.25 \pm 0.29$ & 0.355 \\
\hline \multirow[t]{2}{*}{ At week 2} & Weight & $49.86 \pm 3.56$ & $53.42 \pm 7.91$ & $47.70 \pm 1.99$ & 0.297 \\
\hline & $\mathrm{BCS}$ & $3.30 \pm 0.27^{\mathrm{ab}}$ & $3.58 \pm 0.20^{\mathrm{a}}$ & $3.12 \pm 0.25^{\mathrm{b}}$ & 0.032 \\
\hline \multirow[t]{2}{*}{ At Week 4} & Weight & $50.16 \pm 4.25$ & $52.25 \pm 7.67$ & $48.10 \pm 0.96$ & 0.599 \\
\hline & $\mathrm{BCS}$ & $3.30 \pm 0.27$ & $3.33 \pm 0.41$ & $3.00 \pm 0.00$ & 0.345 \\
\hline \multirow[t]{2}{*}{ At Week 6} & Weight & $48.44 \pm 3.45$ & $49.67 \pm 5.33$ & $48.33 \pm 1.15$ & 0.857 \\
\hline & $\mathrm{BCS}$ & $3.00 \pm 0.00$ & $3.17 \pm 0.26$ & $3.00 \pm 0.00$ & 0.251 \\
\hline \multirow[t]{2}{*}{ At Week 8} & Weight & $46.84 \pm 4.07$ & $49.67 \pm 4.56$ & $48.67 \pm 1.26$ & 0.519 \\
\hline & BCS & $3.10 \pm 0.22$ & $3.17 \pm 0.26$ & $3.17 \pm 0.29$ & 0.895 \\
\hline
\end{tabular}

${ }^{\mathrm{ab}}$ Means within the same row carrying different superscripts were significantly different at $(P \leq 0.05)$.
C: Concentrate
R: Roughage
BCS: Body condition score

Table 3: Effect of feeding different concentrate $(C)$ roughage $(\mathrm{R})$ ratio on daily DM intake of ewes.

\begin{tabular}{|c|c|c|c|c|}
\hline $\begin{array}{l}\text { Advancing weeks (pregnancy } \\
\text { and lactation) }\end{array}$ & $\begin{array}{c}\text { Group } 1 \\
(80 \% \mathrm{C}: 20 \% \mathrm{R})\end{array}$ & $\begin{array}{c}\text { Group } 2 \\
(70 \% \mathrm{C}: 30 \% \mathrm{R})\end{array}$ & $\begin{array}{c}\text { Group } 3 \\
(60 \% \mathrm{C}: 40 \% \mathrm{R})\end{array}$ & $P$-value \\
\hline 1 & $993.25 \pm 8.16$ & $985.17 \pm 11.86$ & $991.38 \pm 9.36$ & 0.181 \\
\hline 2 & $998.57 \pm 1.21$ & $997.71 \pm 2.49$ & $999.14 \pm 1.00$ & 0.187 \\
\hline 3 & $1095.00 \pm 4.54$ & $1097.36 \pm 6.60$ & $1099.00 \pm 3.16$ & 0.214 \\
\hline 4 & $1097.86 \pm 5.63$ & $1097.64 \pm 4.30$ & $1100.00 \pm 0.00$ & 0.376 \\
\hline 5 & $1094.50 \pm 9.83$ & $1097.78 \pm 5.48$ & $1100.00 \pm 0.00$ & 0.182 \\
\hline 6 & $1100.00 \pm 0.00$ & $1099.57 \pm 1.35$ & $1100.00 \pm 0.00$ & 0.381 \\
\hline 7 & $1100.00 \pm 0.00$ & $1100.00 \pm 0.00$ & $1100.00 \pm 0.00$ & --- \\
\hline 8 & $1144.88 \pm 10.02^{b}$ & $1156.07 \pm 9.24^{\mathrm{a}}$ & $1151.67 \pm 10.27^{\mathrm{ab}}$ & 0.053 \\
\hline 9 & $1233.18 \pm 17.10$ & $1221.50 \pm 25.09$ & $1225.86 \pm 17.91$ & 0.442 \\
\hline 10 & $1224.53 \pm 17.83$ & $1228.71 \pm 14.02$ & $1229.50 \pm 17.60$ & 0.773 \\
\hline 11 & $1240.27 \pm 12.95$ & $1239.01 \pm 9.53$ & $1238.54 \pm 8.67$ & 0.931 \\
\hline 12 & $1232.56 \pm 20.15$ & $1241.86 \pm 6.23$ & $1240.72 \pm 9.11$ & 0.249 \\
\hline 13 & $1244.43 \pm 6.21$ & $1243.86 \pm 6.84$ & $1239.64 \pm 6.03$ & 0.204 \\
\hline 14 & $1244.50 \pm 5.55$ & $1245.64 \pm 3.82$ & $1245.14 \pm 5.77$ & 0.883 \\
\hline 15 & $1244.78 \pm 6.94$ & $1245.93 \pm 3.91$ & $1245.07 \pm 5.56$ & 0.894 \\
\hline 16 & $1245.50 \pm 5.31$ & $1244.50 \pm 4.69$ & $1244.78 \pm 4.49$ & 0.894 \\
\hline 17 & $1246.57 \pm 5.21$ & $1245.14 \pm 3.94$ & $1243.07 \pm 7.29$ & 0.392 \\
\hline 18 & $1246.00 \pm 4.94$ & $1245.07 \pm 4.72$ & $1244.86 \pm 6.25$ & 0.879 \\
\hline 19 & $1244.21 \pm 6.86$ & $1244.86 \pm 5.63$ & $1242.71 \pm 8.42$ & 0.787 \\
\hline 20 & $1245.07 \pm 6.28$ & $1243.07 \pm 7.89$ & $1242.14 \pm 8.89$ & 0.693 \\
\hline 21 & $1243.07 \pm 10.16$ & $1240.14 \pm 15.33$ & $1245.00 \pm 5.17$ & 0.617 \\
\hline 22 & $1245.71 \pm 6.60$ & $1244.50 \pm 7.65$ & $1244.86 \pm 6.26$ & 0.921 \\
\hline 23 & $1247.00 \pm 3.65$ & $1243.00 \pm 9.17$ & $1245.43 \pm 6.73$ & 0.437 \\
\hline 24 & $1246.71 \pm 3.61$ & $1245.43 \pm 6.86$ & $1245.50 \pm 4.97$ & 0.832 \\
\hline 25 & $1247.71 \pm 2.95$ & $1244.00 \pm 5.94$ & $1245.86 \pm 4.06$ & 0.200 \\
\hline 26 & $1245.64 \pm 3.76$ & $1244.00 \pm 6.67$ & $1247.36 \pm 2.18$ & 0.280 \\
\hline 27 & $1243.07 \pm 10.16$ & $1240.14 \pm 15.33$ & $1245.00 \pm 5.17$ & 0.617 \\
\hline 28 & $1245.71 \pm 6.60$ & $1244.50 \pm 7.65$ & $1247.36 \pm 2.18$ & 0.280 \\
\hline
\end{tabular}

${ }^{\mathrm{ab}}$ Means within the same row carrying different superscripts were significantly different at $(P \leq 0.05)$. 
Table 4: Effect of feeding different concentrate roughage ratio on body weight and body weight gain of newborn lambs till weaning (Mean \pm SD)

\begin{tabular}{|l|c|c|c|c|}
\hline Variable & $\begin{array}{c}\text { Group 1 } \\
(80 \% \mathrm{C}: 20 \% \mathrm{R})\end{array}$ & $\begin{array}{c}\text { Group 2 } \\
(70 \% \mathrm{C}: 30 \% \mathrm{R})\end{array}$ & $\begin{array}{c}\text { Group 3 } \\
(60 \% \mathrm{C}: 40 \% \mathrm{R})\end{array}$ & $P$-value \\
\hline BW at Birth $(\mathrm{kg})$. & $5.133 \pm 0.37^{\mathrm{a}}$ & $4.817 \pm 0.73^{\mathrm{ab}}$ & $4.337 \pm 0.50^{\mathrm{b}}$ & 0.027 \\
\hline BW at week 2 (kg). & $9.017 \pm 0.80^{\mathrm{a}}$ & $8.06 \pm 0.83^{\mathrm{b}}$ & $7.519 \pm 0.46^{\mathrm{b}}$ & 0.002 \\
\hline BW at week 4 $(\mathrm{kg})$. & $13.650 \pm 1.06^{\mathrm{a}}$ & $12.250 \pm 0.50^{\mathrm{b}}$ & $10.887 \pm 0.64^{\mathrm{c}}$ & 0.000 \\
\hline BW at week 6 (kg). & $17.893 \pm 1.29^{\mathrm{a}}$ & $16.125 \pm 0.25^{\mathrm{b}}$ & $14.625 \pm 0.69^{\mathrm{c}}$ & 0.000 \\
\hline BW at week 8 weaning (kg). & $21.87 \pm 1.50^{\mathrm{a}}$ & $19.63 \pm 0.25^{\mathrm{b}}$ & $17.63 \pm 1.22^{\mathrm{c}}$ & 0.000 \\
\hline ADG From birth to week 2 (g). & $277.45 \pm 38.60^{\mathrm{a}}$ & $231.79 \pm 21.42^{\mathrm{b}}$ & $227.23 \pm 36.77^{\mathrm{b}}$ & 0.033 \\
\hline ADG From week 2 to week 4 (g). & $330.92 \pm 33.58^{\mathrm{a}}$ & $299.11 \pm 26.79^{\mathrm{a}}$ & $240.63 \pm 43.74^{\mathrm{b}}$ & 0.001 \\
\hline ADG From week 4 to week 6 (g). & $303.06 \pm 17.91^{\mathrm{a}}$ & $276.79 \pm 17.86^{\mathrm{ab}}$ & $266.94 \pm 26.43^{\mathrm{b}}$ & 0.019 \\
\hline $\begin{array}{l}\text { ADG From week 6 to week } 8 \\
\text { weaning (g). }\end{array}$ & $284.18 \pm 40.82^{\mathrm{a}}$ & $250.00 \pm 29.16^{\mathrm{ab}}$ & $214.29 \pm 50.51^{\mathrm{b}}$ & 0.023 \\
\hline $\begin{array}{l}\text { Overall ADG from birth till week 8 } \\
\text { (kg) }\end{array}$ & $16.739 \pm 1.23^{\mathrm{a}}$ & $14.807 \pm 0.75^{\mathrm{b}}$ & $13.288 \pm 1.22^{\mathrm{c}}$ & 0.000 \\
\hline
\end{tabular}

BW: Body weight; ADG: Average daily gain.

${ }^{\text {abc }}$ Means within the same row carrying different superscripts were significantly different at $(P \leq 0.05)$.

Table 5: Means $( \pm \mathrm{SE})$ of time of some maintenance behavior of pregnant and lactating ewes in relation to different ratio of roughage and concentrate feeding $(\mathrm{min} / \mathrm{h})$

\begin{tabular}{|l|c|c|c|c|c|c|c|c|}
\hline \multirow{2}{*}{ Behavior } & \multicolumn{4}{|c|}{ Pregnant ewes } & \multicolumn{5}{c|}{ Lactating ewes } \\
\cline { 2 - 9 } & Group 1 & Group 2 & Group 3 & $P$-value & Group 1 & Group 2 & Group 3 & $P$-value \\
\hline Eating & $19.0 \pm 4.8$ & $15.1 \pm 5.93$ & $27.0 \pm 2.05$ & 0.217 & $19.6 \pm 4.01$ & $16.9 \pm 5.56$ & $25.8 \pm 1.8$ & 0.264 \\
\hline Drink & $6.4 \pm 1.2$ & $5.2 \pm 1.39$ & $5.4 \pm 1.12$ & 0.771 & $7.0 \pm 0.83$ & $5.60 \pm 1.28$ & $7.2 \pm 0.80$ & 0.489 \\
\hline Rumination & $6.4 \pm 1.77$ & $6.88 \pm 1.54$ & $12.26 \pm 0.38$ & 0.012 & $6.4 \pm 1.63$ & $7.28 \pm 1.16$ & $11.26 \pm 0.4$ & 0.009 \\
\hline Lying & $12.86 \pm 3.6$ & $18.40 \pm 7.4$ & $14.2 \pm 6.7$ & 0.807 & $13.26 \pm 3.51$ & $21.8 \pm 6.43$ & $16.4 \pm 6.51$ & 0.574 \\
\hline Standing & $5.2 \pm 0.95$ & $7.06 \pm 1.06$ & $2.54 \pm 0.5$ & 0.011 & $5.4 \pm 0.91$ & $7.6 \pm 1.33$ & $2.02 \pm 0.72$ & 0.007 \\
\hline Walking & $3.7 \pm 0.24$ & $3.1 \pm 1.32$ & $0.90 \pm 0.40$ & 0.072 & $8.8 \pm 1.06$ & $3.9 \pm 1.33$ & $1.10 \pm 0.33$ & 0.386 \\
\hline Urination & $0.62 \pm 0.19$ & $0.44 \pm 0.20$ & $0.41 \pm 0.17$ & 0.717 & $0.82 \pm 0.21$ & $0.52 \pm 0.18$ & $0.41 \pm 0.17$ & 0.333 \\
\hline Defecation & $2.02 \pm 0.6$ & $1.16 \pm 0.47$ & $0.61 \pm 0.24$ & 0.138 & $2.42 \pm 0.5$ & $1.48 \pm 0.36$ & $1.08 \pm 0.0$ & 0.058 \\
\hline
\end{tabular}

Table 6: Effect of feeding different concentrate roughage ratio during gestation period on some neonatal behavior

\begin{tabular}{|l|c|c|c|c|}
\hline & $\begin{array}{c}\text { Group 1 } \\
(80 \% \mathrm{C}: 20 \% \mathrm{R})\end{array}$ & $\begin{array}{c}\text { Group 2 } \\
(70 \% \mathrm{C}: 30 \% \mathrm{R})\end{array}$ & $\begin{array}{c}\text { Group 3 } \\
(60 \% \mathrm{C}: 40 \% \mathrm{R})\end{array}$ & $P$-value \\
\hline Birth to stand(min) & $19.75 \pm 0.64$ & $21.20 \pm 0.58$ & $23.25 \pm 0.85$ & 0.014 \\
\hline Birth to udder(min) & $23.75 \pm 0.75$ & $27.40 \pm 0.74$ & $28.5 \pm 1.70$ & 0.009 \\
\hline Birth to suck (min) & $27.00 \pm 0.70$ & $32.40 \pm 0.92$ & $32.75 \pm 0.85$ & 0.000 \\
\hline Suckling attempt & $4.25 \pm 0.36$ & $5.20 \pm 0.37$ & $6.75 \pm 0.47$ & 0.003 \\
\hline
\end{tabular}


Table 7: Effect of feeding different concentrate roughage ratio on reproductive performance of ewes

\begin{tabular}{|c|c|c|c|}
\hline Variables & $\begin{array}{c}\text { Group 1 } \\
(80 \% \mathrm{C}: 20 \% \mathrm{R})\end{array}$ & $\begin{array}{c}\text { Group 2 } \\
(70 \% \mathrm{C}: 30 \% \mathrm{R})\end{array}$ & $\begin{array}{c}\text { Group 3 } \\
(60 \% \mathrm{C}: 40 \% \mathrm{R})\end{array}$ \\
\hline No. of ewe mated & 10 & 10 & 10 \\
\hline No. conceived & 8 & 5 & 4 \\
\hline Abortions/stillbirths & 0 & 0 & 4 \\
\hline No. of lambs born alive & 8 & 5 & 0 \\
\hline No. of lambs aborted/stillborn & 0 & 0 & 4 \\
\hline $\begin{array}{c}\text { Total number of Lambs } \\
\text { produced }\end{array}$ & 8 & 5 & 40 \\
\hline $\begin{array}{c}\text { Conception rate\% } \\
\text { Lambing rate \% } \\
\text { (Lambs produced/ewe lamb } \\
\text { mated) }\end{array}$ & 80 & 50 & 40 \\
\hline Average litter size & 0.8 & 50 & 0.4 \\
\hline
\end{tabular}

C: Concentrate R: Roughage

\section{Conclusion}

It could be concluded that feeding higher concentrate roughage ratio $(80 \mathrm{C} \%: 20 \% \mathrm{R})$ and (70\%C: $30 \% \mathrm{R})$ improved body weight, body weight gain and vigour of newborn lambs and reproductive performance of ewes.

\section{References}

1. Egyptian Ministry of Agricultural Economic statistical book 2009.

2. Momoh OM, Rotimi EA, Dim NI. Breed effect and non-genetic factors affecting growth performance of sheep in a semi-arid region of Nigeria. Journal of Applied Biosciences 2013; 67:5302-7.

3. Silva TP, Marques CA, Torreão JN, Bezerra $\mathrm{RN}$, Araújo MJ, Lima LA. Effect of concentrate supplementation and time scales of evaluation on behavioral and physiological responses of pregnant ewes on grazing system. Acta Scientiarum. Animal Sciences 2016; 38 (1):77-86.

4. Malisetty V, Yerradoddi RR, Devanaboina N, Mallam M , Mitta P. Effect of feeding sorghum straw based complete rations with different roughage to concentrate ratio on dry matter intake, nutrient utilization, and nitrogen balance in Nellore ram lambs. Tropical Animal Health and Production 2014; 46(5):759-64.

5. Missio RL, Brondani IL, Alves Filho DC, Restle J, Arboitte MZ, Segabinazzi LR. Características da carcaça e da carne de tourinhos terminados em confinamento, recebendo diferentes níveis de concentrado na dieta. Revista Brasileira de Zootecnia 2010; 39(7):1610-7.

6. Chen Y, Oba M, Guan LL. Variation of bacterial communities and expression of Toll-like receptor genes in the rumen of steers differing in susceptibility to subacute ruminal acidosis. Veterinary Microbiology 2012; 159:451-9.

7. Maurya VP, Sejian V, Kumar D, Naqvi SMK. Effect of induced body condition score differences on sexual behavior, scrotal measurements, semen attributes, and endocrine responses in Malpura rams under hot semi-arid environment. Journal of Animal physiology and Animal Nutrition 2010; 94: 308-17.

8. Zarazaga LA, Guzman JL, Dominguez C, Perez MC, Prieto R. Effect of plane of nutrition on seasonality of reproduction in Spanish Payoya goats. Journal of Animal Reproduction Science 2004; 87: 253-67.

9. Al-Khozam NM. Effect of peri-ovulatory diet composition on the subsequent development of fertilized sheep ova in vivo and during in vitro culture. M.Sc. thesis, 1994, Aberdeen University, UK.

10. Dwyer C. Maternal behaviour and lamb survival: from neuroendocrinology to practical application. Animal 2014; 8:102-12.

11. Nowak R and Poindron P. From birth to colostrum: early steps leading to lamb survival. Reproduction Nutrition Development 2006; 46:431-46.

12. NRC. Nutrient Requirements of Dairy Cattle, $7^{\text {th }}$ ed. Washington, D.C.: The National Research Council, National Academy Press 2001. 
13. AOAC. Official Method of Analysis. Association of Official Agricultural Chemists. Washington. D.C. and New York: Academic Press 2002: 1-350.

14. Russel AJF, Doney JM, Gunn RG. Subjective assessment of body fat in live sheep. Journal of Agriculture Sciences 1969; 72: 451-4.

15. Dwyer CM, Calvert SK, Farish M, Donbav J, Pickup HE. Breed, litter and parity effects on placental weight and placentome number, and consequences for the neonatal behaviour of the lamb. Theriogenology 2005; 63:1092-110.

16. Pedernera M, Pérez-Sánchez LA and Romero-Aguilar LD et al. Effects of high concentrate supplementation of Saint Croix sheep during peripartum on neonatal lamb behaviour. Journal of Applied Animal Research 2017; 46(1): $720-4$.

17. Duncan DB. Multiple range and multiple F. tests. Biometrics 1955; 11: 1-42.

18. Ferdous MR, Khan MJ, Rashid MA and Kamruzzaman M. Effect of different levels of concentrate supplementation on the performance of Black Bengal goat. Bangladesh Journal of Animal Science 2011; 40: 40-5.

19. Mahfuz SU, Islam MSD, Chowdhury MR, Islam S, Hasan MK, Uddin MN. Influence of concentrate supplementation on production and reproduction performance of female Black Bengal goat. Indian Journal of Animal Research 2018; 52(5): 735-9.

20. Sultana S, Khan MJ, Hassan MR, Khondoker MAMY. Effects of concentrate supplementation on growth, reproduction and milk yield of Black Bengal goats (Caprahircus). The Bangladesh Veterinarian 2012; 29(1): 7 - 16.

21. El-Shakhret KJ, Harb MY, Abu-Zanat M, Tabbaa MJ. Effect of different feeding levels of concentrate on voluntary intake of straw and on productive and reproductive performance of Awassi sheep in Jordan Valley. Agricultural Sciences 1996; 23(2).

22. Nunes PH, Maia PM and Silva RMG et al. Increasing levels of concentrate digestibility, performance and ingestive behavior in lambs. Revista Brasileira de Saúde e Produção Animal 2016; 17(2): 186-94.

23. Cantalapiedra-Hijar C, Yáñez-Ruiz DR, Martín-García AI, Molina-Alcaide E. Effects of forage: concentrate ratio and forage type on apparent digestibility, ruminal fermentation, and microbial growth in goats. Journal of Animal Science 2014; 87:622-31.
24. Aguerre MJ, Wattiaux MA, Powell JM, Broderick GA, and Arndt C. Effect of forage-toconcentrate ratio in dairy cow diets on emission of methane, carbon dioxide, and ammonia, lactation performance, and manure excretion. Journal of Dairy Science 2011; 94:3081-93.

25. Desnoyers M, Duvaux-Ponter C, Rigalma K, Roussel S, Martin O, Giger-Reverdin S. Effect of concentrate percentage on ruminal $\mathrm{pH}$ and timebudget in dairy goats. Journal of Animal Science 2008; 2:1802-8.

26. Murphy M, Akerlind M, Holtenius K. Rumen fermentation in lactating cows selected for milk fat content fed two forage to concentrate ratios with hay or silage. Journal of Dairy Science 2000; 83:756-4.

27. Hegarty M, Montello DR, Richardson AE, Ishikawa T, Lovelace K. Spatial abilities at different scales: individual differences in aptitude test performance and spatial layout learning. Intelligence 2006; 34:151-76.

28. Cloete JJE, Hoffman LC, Cloete SWP. A comparison between slaughter traits and meat quality of various sheep breeds: wool, dual purpose and mutton. Meat Science 2012; 91:318-24.

29. Carvalho S, Brochier MA, Pivato J, Teixeira RC, Kieling R. Desempenho e avaliação econômica da alimentação de cordeiros confinados com dietas contendo diferentes relações volumoso: concentrado. Ciência Rural 2007; 37(5):1411-7.

30. Karim SA and Rawat PS. Growth performance and carcass characteristics of lambs raised on varying proportions of roughage and concentrate. Indian Journal of Animal Sciences 1997; 67: 902-5.

31. Noel A. Claffey, Alan G. Fahey, Vasiliki Gkarane, Aidan P. Moloney, Frank J. Monahan, and Michael G. Diskin. Effect of forage to concentrate ratio and duration of feeding on growth and feed conversion efficiency of male lambs. Translation Animal Science 2018; 2: 419-27.

32. Santra A and Karim SA. Effect of dietary roughage and concentrate ratio on nutrient utilization and performance of ruminant animals. Animal Nutrition and Feed Technology 2009; 9: 113-35.

33. Venkateshwarlu V, Venkateswarlu $\mathrm{M}$, Ramana Reddy Y, Harikrishna $\mathrm{CH}$. Effect of feeding maize stover based complete rations on growth and carcass characteristics in Nellore $\mathrm{x}$ Deccani ram lambs. Indian Journal of Animal Nutrition 2014; 31: 36-43.

34. Santra A and Karim SA. Nutrient utilization and growth performance of defaunated and faunated 
lambs maintained on complete diets containing varying proportion of roughage and concentrate. Animal Feed Science and Technology 2002; 101:87-99.

35. Singla M, Sirohi AS, Lamba JS, Ahuja CS. Effect of soaked and boiled concentrate feeding on growth, tvfa's production and blood biochemistry of stall-fed beetal kids. Indian journal of Animal Research 2014; 48 (5): 448-51.

36. Sudheer Babu A, Srinivasa Rao D, Nagalakshmi D, Ramana Reddy Y. Effect of feeding various roughage based processed complete rations on growth performance and carcass characteristics in growing ram lambs. Livestock Research for Rural Development 2013; 25(5).

37. Minervino AHH, Kaminishikawahara CM and Soares FB et al. Behaviour of confined sheep fed with different concentrate sources. Brazilian Journal of Veterinary and Animal Science 2014; 66(4):1163-70.

38. Dwyer C. Behavioral development in the neonatal lamb: effect of maternal and birth-related factors. Theriogenology 2003; 59:1027-50.

39. Dwyer CM. The welfare of the neonatal lamb. Small Ruminant Research 2008; 76:31-41.

40. Symonds M, Sebert S, Budge H. Nutritional regulation of fetal growth and implications for productive life in ruminants. Animal 2010; 4:107583.

41. Alamy M and Bengelloun WA. Malnutrition and brain development: an analysis of the effects of inadequate diet during different stages of life in rat.
Neuroscience and Biobehavioral reviews Journal 2012; 36:1463-80.

42. Ibarra D, Laborde D, Van-Lier E. Repeatability and relationship with field mating performance of a serving capacity pen test in rams. Small Ruminant Research 2000; 37: 156-69.

43. Amer HA and Hazzaa AM. The effect of different progesterone protocols on the reproductive efficiency of ewes during the nonbreeding season. Veterinarski Arhiv 2009; 79: 19-30.

44. Ozyurtlu N, Kucukaslan I and Cetin Y. Characterization of Oestrous Induction Response, Oestrous Duration, Fecundity and Fertility in Awassi Ewes During the Non-Breeding Season Utilizing both CIDR and Intravaginal Sponge Treatments. Reproduction in Domestic Animals 2010; 45:464-7.

45. Khalaf AM, Doxy DL, Baxter JT. A study of some reproductive and productive trails in a flock of awassi sheep. World Review of Animal Production 1979; 3:29-33.

46. Lassoued N, Rekik M, Mahouachi M, Ben Hamouda M. The effect of nutrition prior to and during mating on ovulation rate, reproductive wastage, and lambing rate in three sheep breeds. Small Ruminant Research 2004; 52:117-25

47. Henniawati $\mathrm{H}$ and Fletcher ICX. Reproduction in Indonesian sheep and goats at two levels of nutrition. Animal Reproduction Science 1986; 12: 77-84. 